\title{
Development and evaluation of a loop-mediated isothermal amplification assay for the rapid detection of porcine cytomegalovirus under field conditions
}

\author{
Jin-Long Yang ${ }^{1}$, Su-Hui Zhang ${ }^{1}$, Zuo-Hua Liu ${ }^{1}$, Rui Yang ${ }^{1}$, Yong Huang ${ }^{1}$ and Ming Wen ${ }^{2 *}$
}

\begin{abstract}
Background: Porcine cytomegalovirus (PCMV) induces silent infection in adult pigs but more frequently causes fatal, generalized infection in newborn piglets. This study aimed to develop a new loop-mediated isothermal amplification (LAMP) method for the sensitive, rapid, and inexpensive detection of PCMV under field conditions.

Methods: Tissue obtained from nine-week-old PCMV-free Landrace pigs or pig samples from postmortem examinations were analyzed. The samples were found to have clinical signs and lesions consistent with inclusion body rhinitis. Six specific primers were designed by targeting the PCMV DNA polymerase (DPOL) DNA. The LAMP reaction was optimized in a water bath. The sensitivity and specificity of LAMP and polymerase chain reaction (PCR) were compared.

Results: PCMV DNA was amplified at $65^{\circ} \mathrm{C}$, and the result could be detected as early as 30 min into the reaction. Positive reactions could be visualized by the naked eye as a color change brought on by the addition of SYBR Green. The sensitivity and specificity of LAMP were found to be similar to those of the PCR.

Conclusions: LAMP is a high-throughput technique for the detection of PCMV and has a high specificity, sensitivity and simplicity; these factors make it suitable for detection of PCMV under field conditions.
\end{abstract}

Keywords: Porcine cytomegalovirus, Loop-mediated isothermal amplification, Landrace pigs, Field detection

\section{Background}

Porcine cytomegalovirus (PCMV) is a $\beta$-herpesvirus that was first described in 1955 [1]. It shares sequence homology with human herpesviruses 6 and 7 and human cytomegalovirus (HCMV) [2-6]. It usually induces silent infection in adult pigs but often a fatal, generalized infection in newborn piglets, with $90 \%$ of pigs in the UK being seropositive [3,7]. PCMV has been known to cross the placenta and infect the fetuses in pregnant sows, leading to fetal death or birth of weak piglets $[5,6]$.

PCMV is of particular concern because, similar to its human counterpart, it is characterized by high seroprevalence in the swine population, has diverse clinical

\footnotetext{
* Correspondence: a1921538734@qq.com

${ }^{2}$ Animal Science College of Guizhou University, Guiyang, Guizhou 550025, China

Full list of author information is available at the end of the article
}

manifestations, and establishes latent infection $[8,9]$. It is one of the major causes of morbidity and mortality in immunocompromised pigs [10]; therefore, diagnosis at an early stage is essential. However, clinical diagnosis of this disease can be difficult, since veterinarians need to consider various underlying diseases and clinical presentations.

Serological detection is one of the most widely used methods for detecting the reactivation of PCMV infection [11-13]. In addition to this technique, nucleic acidbased methods such as polymerase chain reaction (PCR) are increasingly being used for identifying and detecting the pathogens $[14,15]$. The accuracy and sensitivity of PCR for the detection of specific diseases are higher than other methods [15-17]. PCR can be applied for detecting PCMV infection, and it is considered more useful than other techniques for the prediction of PCMV [18].

\section{Biomed Central}


Although PCMV can be effectively and accurately detected in a laboratory setting using these procedures, these methods are time-consuming, laborious and require expensive equipment, rendering them unfavorable for wide-scale use or for use under field conditions. In Japan, the PCR method is not widely used in clinical practice for PCMV detection due to the higher costs involved in this technique, as compared to the serological detection method [19]. Therefore, a simple, rapid, sensitive, economical and practical method is required for the detection of PCMV [20].

Loop-mediated isothermal amplification (LAMP) is a DNA amplification method that was recently developed as a low-cost alternative for the detection of certain diseases. LAMP is a rapid and simple method of specific nucleic acid amplification that can be carried out within an hour [21,22]. Only a simple incubator is required for the LAMP technique [21]. At the end of the reaction, the presence or absence of target DNA is visually judged by change in color after the addition of SYBR Green I to the reaction mixture, or by the appearance of a white magnesium pyrophosphate precipitate; thus, differentiating positive from negative results is relatively easy $[23,24]$. It also allows for a high degree of specificity in the detection of specific pathogens. Since it only requires simple equipment, DNA detection with this technique is cost-effective. This method has previously been applied for the simple and real-time detection of specific pathogens such as enteroviruses $[25,26]$ and Trypanosoma brucei gambiense [27].

Currently, LAMP is used in developing countries for the rapid detection of certain pathogens; however, to the best of our knowledge, no study has investigated the application of LAMP for detecting PCMV. Therefore, we aimed to optimize LAMP with the DNA polymerase (DPOL) target sequence from PCMV strain OF-1 for the simple, rapid, cost-effective and sensitive detection of PCMV under field conditions.

\section{Methods}

\section{DNA preparation}

Ten 9-week-old PCMV-free Landrace pigs were purchased from the Experimental Animal Center (Chongqing Medical University, China). All animal care and study protocols were approved by the Animal Studies Committee of Chongqing, China (Certificate Number 2007-0001). Five of these pigs were orally administered a virulent PCMV strain (laboratory-adapted strain, No. 100218; Research Center of Pig Diseases, Chongqing Academy of Animal Science, China), using $0.1 \mathrm{~mL}$ of $10^{3} \mathrm{LD}_{50}$ per pig. The remaining five pigs were orally administered an equal volume of water as the control. Three pigs from each group were sacrificed $48 \mathrm{~h}$ post-infection, and their spleen and liver were aseptically removed and stored immediately in $1.5 \mathrm{~mL}$ labeled snap-cap tubes. Crude DNA was obtained by boiling: approximately $50 \mathrm{mg}$ of tissue was homogenized in $500 \mu \mathrm{L}$ of $1 \%$ sodium dodecyl sulfate (SDS) in $100 \mathrm{mM}$ Tris- $\mathrm{HCl}$ (pH 8.0), boiled for $10 \mathrm{~min}$, and centrifuged at 10,000 $\mathrm{g}$ for $5 \mathrm{~min}$. The supernatant was transferred to a new tube and used immediately [28,29].

\section{Preparation of standard DNA template}

Briefly, PCMV-infected cells were harvested by centrifugation. The pellets were processed using a DNA extraction kit (Tiangen Biotech, Beijing, China) according to the manufacturer's recommendations. The genomic DNA pellet was resuspended in $50 \mu \mathrm{L}$ TE buffer (pH 8.0) [30].

The DNA concentration was determined using a spectrophotometer (Bio-Rad Smartspec-3000; Bio-Rad Laboratories, Hercules, CA, USA) according to the manufacturer's instructions. On the basis of the molecular weight, the standard DNA copy number was calculated using the equations described by Ke et al. [31]. The standard DNA was diluted, divided into aliquots, and stored at $-20^{\circ} \mathrm{C}$ until analysis [28].

\section{Design of LAMP primers}

Six specific LAMP primers were designed to detect PCMV DNA. A specific define (DPOL) within the PCMV gene (Genbank Accession No. AF268041.2) was selected as the target for LAMP. The LAMP primers were designed with the Primer Explorer V4 program (http://primerexplorer.jp). The sequences and locations of the primers are shown in Table 1.

\section{Optimization of the LAMP reaction}

A LAMP amplification kit (Eiken Chemical Co. Ltd., Tokyo, Japan) was used for the LAMP reaction. The reaction was prepared according to the manufacturer's instructions in a total volume of $25 \mu \mathrm{L}$. The final primer concentrations used were described by Yang et al. [32]. The reaction time was optimized by incubating the mixture for $10,20,30,40,50$ or $60 \mathrm{~min}$ at a pre-determined temperature $\left(65^{\circ} \mathrm{C}\right)$. The reaction temperature was optimized by incubating the mixture at $58,59,60,61,62$, 63,64 or $65^{\circ} \mathrm{C}$ for a pre-determined time $(60 \mathrm{~min})$. The reaction was terminated by heating at $85^{\circ} \mathrm{C}$ for $2 \mathrm{~min}$. The LAMP products $(5 \mu \mathrm{L})$ were electrophoresed on $2 \%$ agarose gels and stained with ethidium bromide to determine the optimal reaction conditions.

\section{Visual observation of LAMP products}

Amplified DNA could be visualized as white turbidity of the LAMP reaction mixture as a result of magnesium pyrophosphate, which is a by-product of the reaction. The LAMP amplicons in the reaction tube were visually detected after the addition of $1.0 \mu \mathrm{L}$ of original SYBR 
Table 1 Primers used for LAMP

\begin{tabular}{|c|c|c|c|}
\hline Primer & Type & Length & Sequence \\
\hline F3 & Forward outer & $18-n t$ & 5'- TATCTGGTTCTGGCGGAC - $3^{\prime}$ \\
\hline B3 & Backward outer & 23-nt & 5'- AGCATATTTCTCTITCTAGTCTC -3' \\
\hline FIP & Forward inner (F1C + F2) & 46-mer(F1c:25-nt, F2:21-nt) & 5'- TAGCAGATGCTTCCATATGGTAATT-GGGCAGATATTGTATACAGGA -3' \\
\hline BIP & Backward inner(B1C + B2) & 43-mer (B1c:22-nt, B2:21-nt) & 5'- TTCTAAGTTGGCCTACTTGCCC-ATGAAGGATACACGTGAACAC -3' \\
\hline LF & Loop Forward & $23-n t$ & 5'- ACAACTCCTTAACGATCACCGAA -3' \\
\hline LB & Loop Backward & $25-n t$ & 5'-ATCAGGAAGGTGATAAATGATGGAC -3' \\
\hline
\end{tabular}

Green I (1,000× dilution; Molecular Probes, SigmaAldrich Corporation, St. Louis, MO USA). The color of the solution changed from light orange to green in the presence of the LAMP amplicons, whereas the color of the samples without amplicons did not change. The white turbidity in the reaction mixture was also inspected prior to the addition of SYBR Green I. The reaction mixture $(5 \mu \mathrm{L})$ was loaded and run on $2 \%$ agarose gel, stained with ethidium bromide, and visualized by ultraviolet (UV) transillumination. A charge-coupled device camera (TILL Photonics LLC, Martinsreid, Germany) was used to photograph the results [28].

\section{PCR detection}

The target sequences were amplified by the ABI AmpliTaq Gold DNA polymerase system with a 96-well thermal cycler (Veriti FAST 96-well; Bio-Rad Corp., Hercules, CA, USA). The assay was carried out according to the method of Hamel et al. [15], and a $780 \mathrm{bp}$ target sequence was amplified.

\section{Specificity and sensitivity of LAMP}

The specificity of LAMP was tested using standard DNA templates and templates from other beta herpesviruses, namely, human herpesvirus 6 (HHV-6), HHV-7, and HCMV (Strains were purchased from the National Center for Medical Culture Collection, China). The reaction was performed at $65^{\circ} \mathrm{C}$ for $60 \mathrm{~min}$. PCR was carried out as described for the control assay.

Tenfold serial dilutions $\left(1 \times 10^{3}\right.$ to $1 \times 10^{-1}$ copies $\left./ \mu \mathrm{L}\right)$ of standard DNA were used to determine the detection limit of the assay, and $1 \mu \mathrm{L}$ of each dilution was used for the LAMP assay. The reactions were performed at $65^{\circ} \mathrm{C}$ for $60 \mathrm{~min}$, and the results of this assay were compared with the PCR results.

\section{Application of LAMP to detect PCMV in animal tissues}

To evaluate the optimal conditions for the detection of PCMV via LAMP, total DNA was extracted from the spleen and liver of experimentally infected pigs at $48 \mathrm{~h}$ post-infection. Twenty tissue samples obtained by postmortem examinations of the pigs showed the clinical signs and lesions consistent with inclusion body rhinitis; these samples were also analyzed by LAMP and PCR.

\section{Results}

\section{Optimal conditions for LAMP reaction}

We determined the optimal temperature and time for the LAMP reaction for the detection of PCMV. Amplicons were formed at $60,61,62,63,64$ and $65^{\circ} \mathrm{C}$, but the clearest products were obtained at 63,64 and $65^{\circ} \mathrm{C}$ (Figure 1A); the efficiencies of the LAMP reaction at these three temperatures were identical. Meanwhile, LAMP products were detected in the reaction mixture at $65^{\circ} \mathrm{C}$ within as little as $30 \mathrm{~min}$ (Figure 1B). Although well-formed bands could be detected within as early as $30 \mathrm{~min}$, the optimum reaction time at $63-65^{\circ} \mathrm{C}$ was determined as $40 \mathrm{~min}$ to ensure the detection of templates at a lower concentration.

\section{Specificity and sensitivity of LAMP}

The specificity of LAMP and PCR was examined for the detection of DNA templates extracted from the four viruses tested (HHV-6, HHV-7, HCMV, and PCMV); however, only PCMV templates tested positive (Figure 2A). The PCR results (Figure 2B) correlated well with those obtained by LAMP. These results indicate that the specificity of the LAMP for the detection of PCMV was similar to that of the PCR assay.

Furthermore, the detection limits of LAMP and PCR, which were determined using standard DNA templates, were found to be similar (Figure 3). Thus, both these methods showed a similar sensitivity in terms of the detection limit.

\section{Visual detection of LAMP products}

No white turbidity was observed in the reaction mixtures containing $1.0 \times 10^{-1}$ to $1.0 \times 10^{1}$ copies $/ \mu \mathrm{L}$ of standard DNA templates, but white turbidity could be observed in the reaction mixtures containing $1.0 \times 10^{2}$ to $1.0 \times 10^{3}$ copies $/ \mu \mathrm{L}$ (Figure $4 \mathrm{~A}$ ). As shown in Figure 4B, the solution color changed from orange to green from $1.0 \times 10^{1}$ to $1.0 \times 10^{3}$ copies $/ \mu \mathrm{L}$ of standard DNA template $/ \mu \mathrm{L}$, but not for $1.0 \times 10^{-1}$ to $1.0 \times 10^{0} \mathrm{cop}$ ies $/ \mu \mathrm{L}$. Therefore, the LAMP detection limit was $1.0 \times 10^{2}$ copies $/ \mu \mathrm{L}$ with respect to the formation of white turbidity, and 10 copies with SYBR Green I. Thus, the color-change method is 10 times more 


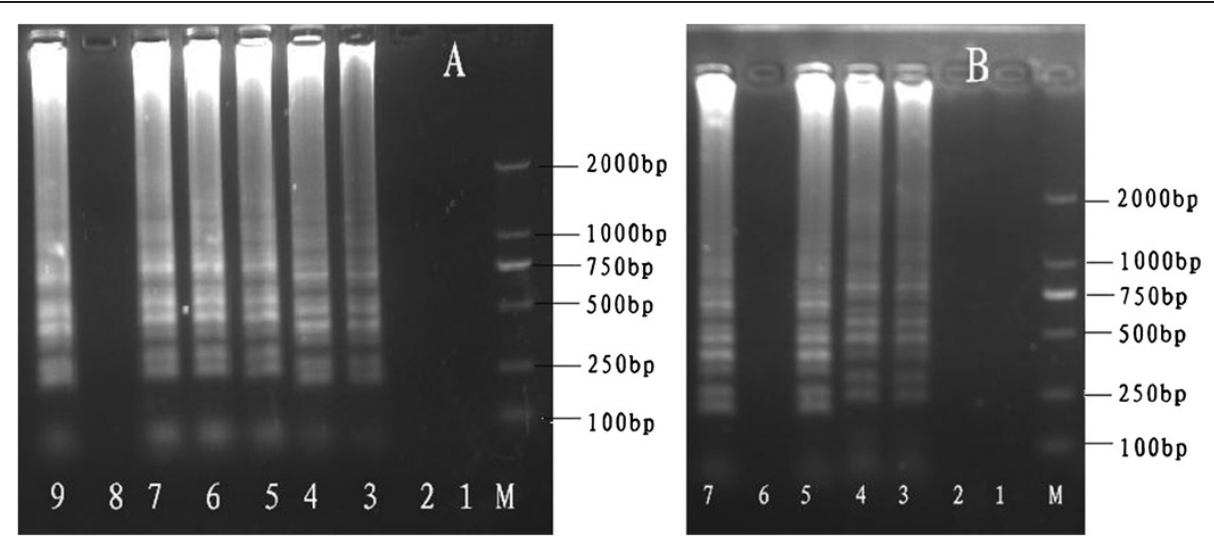

Figure 1 Determining the optimal temperature and time for LAMP. (A) Determination of the optimal temperature. Lane M, DL-2000 DNA marker; Lanes 1-9: Reaction for $60 \mathrm{~min}$ at 58,59,60, 61, 62, 63 and $64^{\circ} \mathrm{C}$; negative control; and reaction at $65^{\circ} \mathrm{C}$. (B) Determination of the optimal time. Lane M, DL-2000 DNA marker; Lanes 1-5 and 7: Reaction for 10, 20, 30, 40, 50 and 60 min $\left(65^{\circ} \mathrm{C}\right)$, respectively; Lane 6: -, negative control. All LAMP products were electrophoresed on $2 \%$ agarose gels and stained with ethidium bromide.

sensitive than the visual observation method for the detection of amplification products.

\section{Application of the LAMP assay for PCMV detection}

The application of the LAMP assay was evaluated by analyzing PCMV-infected pig tissues. DNA extracted by the tissue-boiling method showed a typical ladder pattern (Figure 5). The spleen and liver samples tested positive for PCMV. The twenty pig tissue samples obtained by postmortem examination, which exhibited the clinical signs and lesions consistent with inclusion body rhinitis, were analyzed using LAMP and PCR. Of these, 18 tested positive and 2 tested negative in both the PCR and LAMP assays. Results from both LAMP and PCR were consistent (Figure 5).

\section{Discussion}

Since prevention and early detection are the most logical strategies for pathogen control, the most effective method of disease control is routine screening for pathogens [33]. Sensitive and rapid methods are required for the detection of PCMV under field conditions. However, thus far, there is no practical, simple and rapid method for the diagnosis of PCMV under field conditions.

The detection of PCMV DNA is often performed using PCR-based assays, and the majority of these assays are developed in-house. The individual laboratory determines the performance, verification and validation of such assays. As a result, these assays may vary with regard to specimen type, target DNA, nucleic acid extraction method, or detection method. There is a need for a standardized assay to detect PCMV DNA that can be
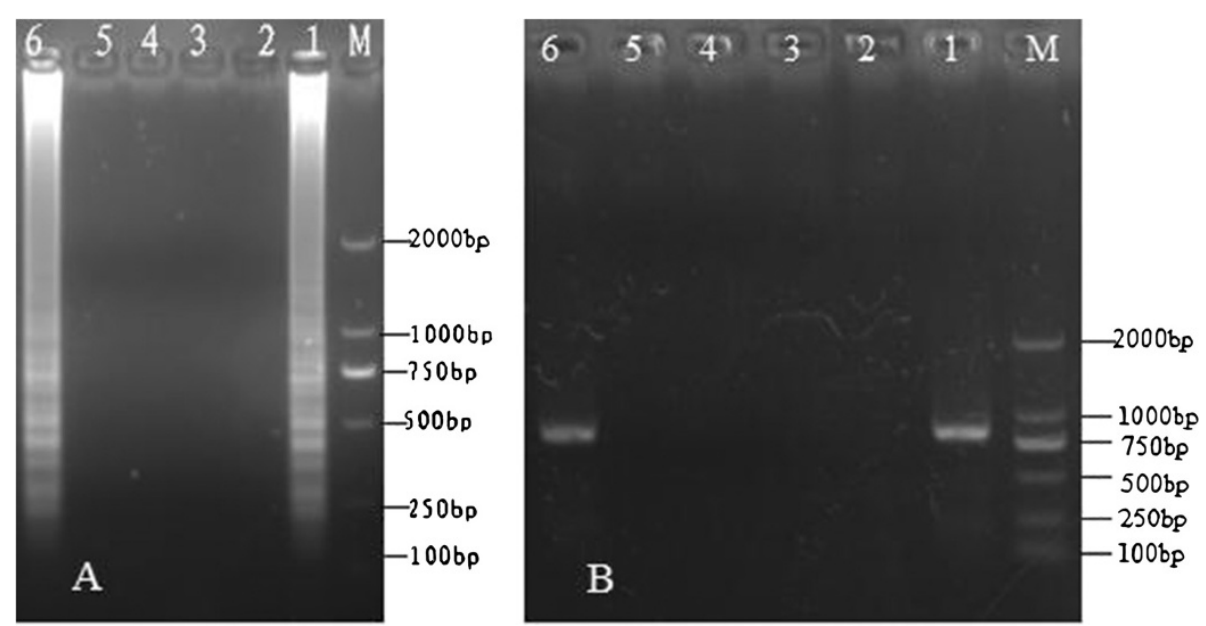

Figure 2 Specificity of the PCMV-LAMP assay and PCR. (A) Specificity of LAMP among different species. (B) Specificity of PCR among different species. M: DL-2000 DNA ladder marker; 1: +, positive control; 2: -, negative control; 3: human herpesvirus 6 (HHV-6); 4: HHV-7; 5: HCMV; and 6: PCMV. All products were electrophoresed on 2\% agarose gels and stained with ethidium bromide. 


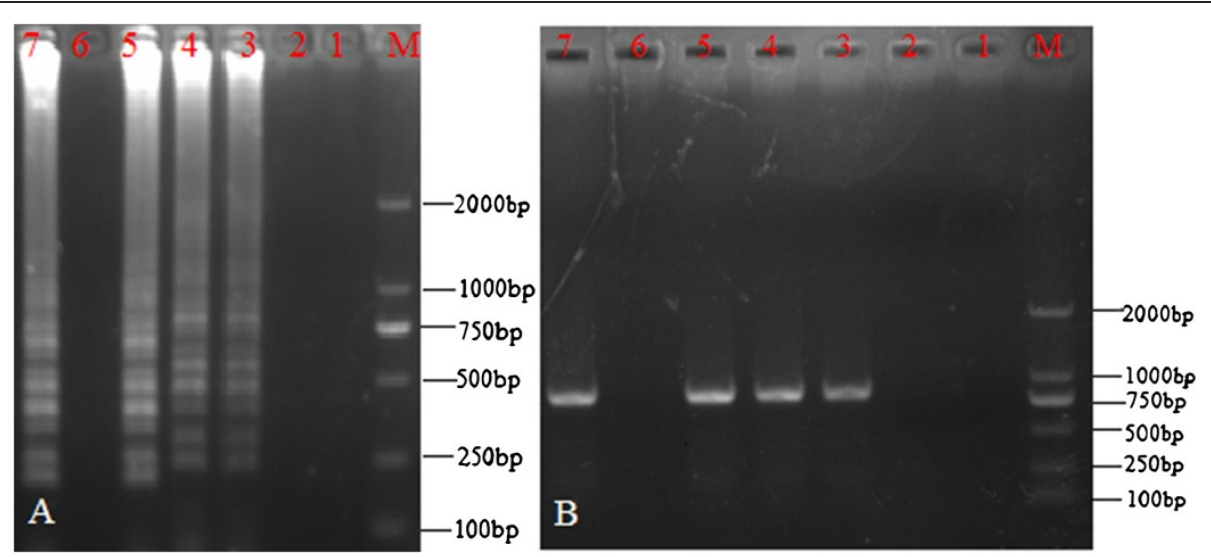

Figure 3 Sensitivity of the LAMP and PCR. (A) Sensitivity of LAMP. (B) Sensitivity of PCR. M, DL-2000 DNA marker; 1-5, reaction carried out using 10-fold serial dilutions of standard PCMV DNA $\left(1.0 \times 10^{3}\right.$ copies $\left./ \mu \mathrm{L}\right): 1: 1.0 \times 10^{-1}$ copies $/ \mu \mathrm{L}, 2: 1.0 \times 10^{0} \mathrm{copies} / \mu \mathrm{L}$, 3: $1.0 \times 10^{1} \mathrm{copies} / \mathrm{\mu L}$, 4: $1.0 \times 10^{2}$ copies $/ \mu \mathrm{L}, 5: 1.0 \times 10^{3}$ copies/ $\mu \mathrm{L}$, respectively; Lane 6: -, negative control, Lane 7: +, positive control. All products were electrophoresed on $2 \%$ agarose gels and stained with ethidium bromide.

broadly applied in clinical practice and enable the establishment of clinically significant cutoffs [34].

LAMP has successfully been used to diagnose pathogenic infections in humans and animals $[35,36]$. In our study, no cross-reaction with the other viruses tested was noted in the LAMP assay, similar to the case with PCR. Furthermore, the specificity of LAMP was not affected by non-target genomic DNA in the reaction mixture, which is a highly desirable trait in a diagnostic system [21]. As shown by the results of the present study, the LAMP method was highly sensitive for the detection of PCMV. Consistent with previous reports,

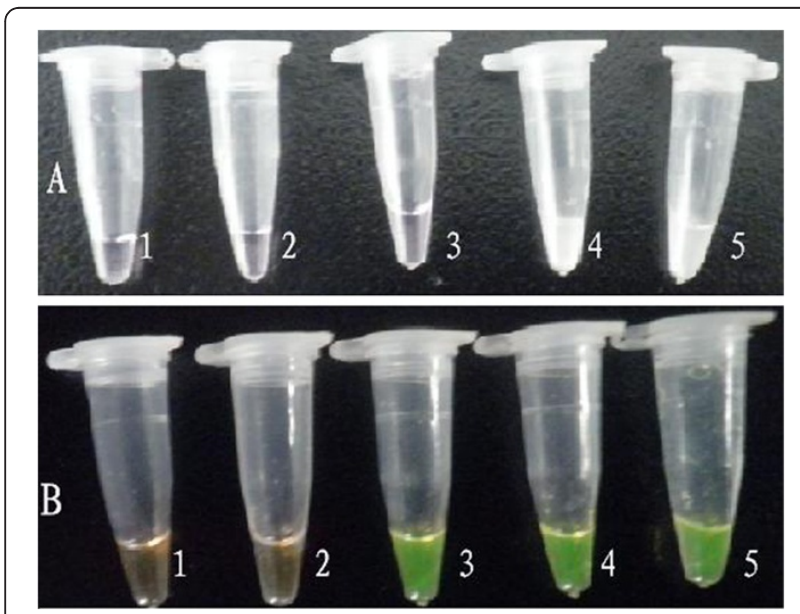

Figure 4 Detection of LAMP products by observing white turbidity and color of the reaction mixture. (A) White turbidity of the reaction mixture by magnesium pyrophosphate; (B) Green color of the reaction mixture after the addition of SYBR Green I. 1-5, reaction carried out using 10-fold serial dilutions of standard PCMV DNA $\left(1.0 \times 10^{3}\right.$ copies/ $\left.\mu \mathrm{L}\right): 1: 1.0 \times 10^{-1}, 2: 1.0 \times 10^{0}, 3: 1.0 \times 10^{1}$, 4: $1.0 \times 10^{2}$, and $5: 1.0 \times 10^{3}$ copies $/ \mu \mathrm{L}$.
LAMP showed the same level of sensitivity as PCR $[37,38]$.

The optimal conditions for PCMV detection by LAMP were determined to be $63-65^{\circ} \mathrm{C}$ for $40 \mathrm{~min}$. However, the LAMP assay involves fewer steps than the PCR assay, and does not require expensive equipment to attain a high level of precision [39]. The LAMP assay is more rapid than PCR for the detection of animal

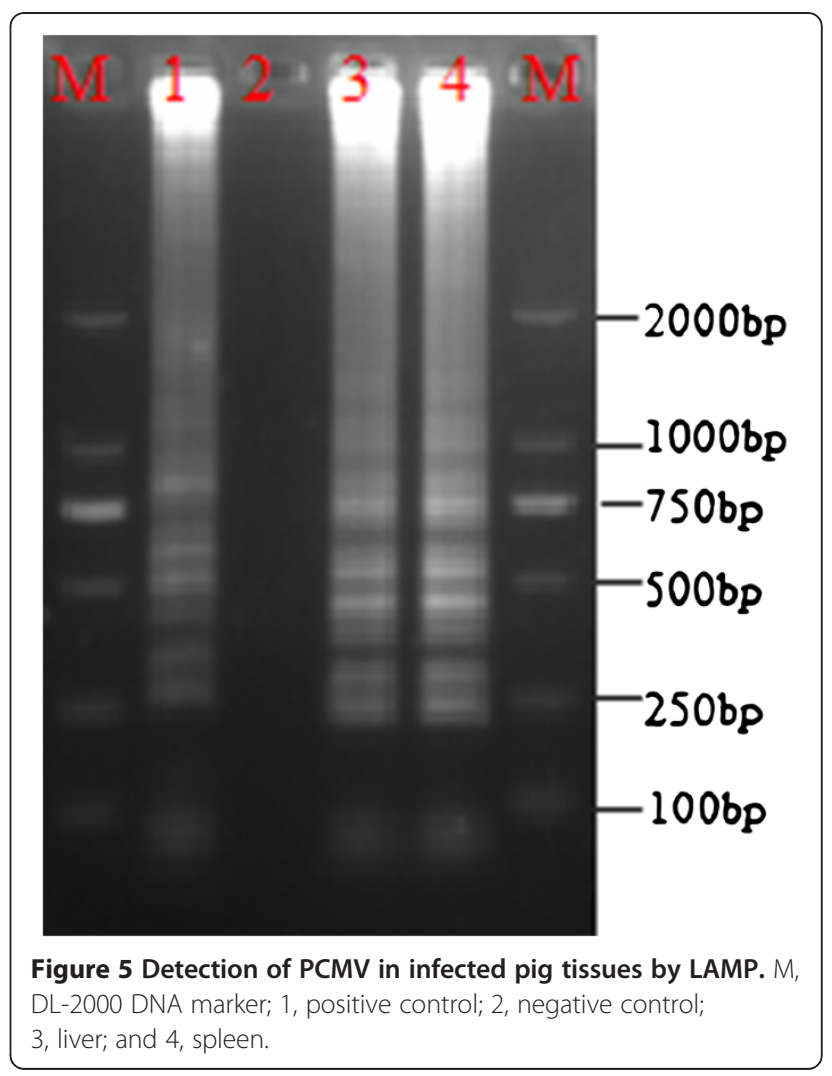


pathogens, which requires at least $2-3 \mathrm{~h}$ for detection [37]. The time required for diagnosis is considered crucial for the diagnosis of pathogenic infections, making LAMP the obvious choice for diagnosing PCMV. In addition, LAMP is ideal for on-site testing, particularly in situations where time is a critical factor, such as when material is subject to quarantine controls.

Furthermore, in the LAMP assay, amplification can be detected as fluorescence by the naked eye, indicating that this assay can be applied in the field. The appearance of color change indicating a positive result occurs after the addition of SYBR Green I; this is a simple and effective method of detecting LAMP amplification products, eliminating the need for gel electrophoresis and ethidium bromide staining [27]. The orange color of the dye changes to green under natural light in the case of a positive reaction [40]. The sensitivity of detection based on the presence of white turbidity was inferior to that based on the color change with SYBR Green I or electrophoresis (Figures 3 and 4); ten-fold more copies of template DNA are required so that a positive reaction in terms of white turbidity can be visually detected. Quantitative detection is difficult in the LAMP assay, but inspection with the naked eye is simple and rapid. LAMP can potentially be used under field conditions even by non-specialists (for example, to carry out surveillance at ports of entry or in the nursery industry) and in small or regional laboratories where nucleic acid-based testing is not currently performed and equipment is limited [41]. No expensive equipment is necessary to obtain a high level of precision equivalent to or greater than that obtained with other PCR techniques. Therefore, this method of detection may facilitate the application of LAMP, especially in the field, where the availability of equipment and expertise may be limited.

A previous study has reported that earlier detection of infection results in earlier treatment and consequently, earlier recovery [37]. Our final goal was to establish a simple and rapid diagnostic method for the specific detection of PCMV under field conditions. To perform LAMP under field conditions, it is crucial to have a suitable nucleic acid extraction technique that requires minimal equipment and can produce sufficient DNA within a short time. The only equipment required in the LAMP assay is a water bath; this is essential for both DNA preparation and nucleic acid amplification. Thus, the LAMP assay can be adopted in most situations where a rapid diagnosis is required, without the need for complicated equipment and technical training. Thus, LAMP is a more rapid method of detection than PCR, even when the PCMV titers are very low. This is due to the high sensitivity of LAMP and its detection limit of approximately 10 copies. We recommend that this technique be applied routinely for the early detection of PCMV, so that adequate countermeasures can be adopted before infections become epizootic [31]. Nevertheless, it must be clarified that the viral copy numbers in this study are not accurate, because we did not use a purified recombinant plasmid containing the target gene for these assays. Further studies with a purified recombinant plasmid are required to improve this assay technique.

In summary, the LAMP protocol described here is a new, inexpensive, and rapid method with high sensitivity and specificity for the detection of PCMV. No complicated technical operations, experimental conditions, or special equipment is required for this technique; only a simple water bath is necessary. Therefore, LAMP is an advantageous diagnostic tool for the specific detection of PCMV infection in animals under laboratory and field conditions.

\section{Competing interests}

The authors declare that they have no competing interests.

\section{Authors' contributions}

$J L Y, Z H L, S H Z$ and RY carried out most of the experiments and wrote the manuscript. MW critically revised the manuscript and the experiment design. All of the authors read and approved the final version of the manuscript.

\section{Acknowledgments}

This work was supported by the Fund for Chongqing Key Programs for Science and Technology Development (Application technology research and development, cstc2012gg-yyjsB80005); Key Laboratory breeding project of animal epidemic disease and public health on veterinary of Guizhou province(Z113223); Fund for Chongqing Agriculture Development (11405); National key Technology Research and Development Program of the Ministry of Science and Technology of China (Grant No. 2010BAD4B01-8) and earmarked fund for Modern Agro-industry Technology Research System (No. CARS-43-15)

\section{Author details}

${ }^{1}$ Chongqing Academy of Animal Science, Chongqing 402460, China. ${ }^{2}$ Animal Science College of Guizhou University, Guiyang, Guizhou 550025, China.

Received: 1 April 2012 Accepted: 21 December 2012

Published: 29 December 2012

\section{References}

1. Done JT: An "inclusion-body" rhinitis of pigs. Vet Rec 1955, 67:525-527.

2. Goltz M, Widen F, Banks M, Belak S, Ehlers B: Characterization of the DNA polymerase loci of porcine cytomegaloviruses from diverse geographic origins. Virus Genes 2000, 21:249-255.

3. Fishman JA, Rubin RH: Infection in organ-transplant recipients. New Engl J Med 1998, 338:1741-1751.

4. Widen F, Goltz M, Wittenbrink N, Ehlers B, Banks M, Belak S: Identification and sequence analysis of the glycoprotein $B$ gene of porcine cytomegalovirus. Virus Genes, 23:339-346. 6. 4

5. Corner AH, Mitchell D, Julian RJ, Meads EB: A generalized disease in piglets associated with the presence of cytomegalic inclusion. J Comp Pathol 1964, 74:192-199.

6. Ohlinger V: In Herpesvirus Diseases of Cattle, Horses, and Pigs. Edited by Wittmann G. Boston: Kluwer; 1989:326-333.

7. Rupasinghe $V$, Iwatsuki-Horimoto $K$, Sugii $S$, Horimoto T: Identification of the porcine cytomegalovirus major capsid protein gene. J Vet Med Sci 2001, 6:609-618.

8. Edington N, Plowright W, Watt RG: Generalized porcine cytomegalic inclusion disease: distribution of cytomegalic cells and virus. J Comp Pathol 1976, 86:191-202. 
9. Narita MM, Kawamura SH, Haritani M, Moriwaki M: Pathologic changes in pigs with prednisolone-induced recrudescence of herpesvirus infection. Am J Vet Res 1985, 46:1506-1510.

10. Guedes MI, Risdahl JM, Wiseman B, Molitor TW: Reactivation of porcine cytomegalovirus through allogeneic stimulation. J Clin Microbio/ 2004, 4:1756-1758.

11. Tajima T, Hironao T, Kajikawa T, Kawamura H: Application of enzyme-linked immunosorbent assay for the seroepizootiological survey of antibodies against porcine cytomegalovirus. J Vet Med Sci 1993, 55:421-424.

12. Tajima T, Kawamura H: Serological relationship among porcine cytomegalovirus Japanese isolates and a UK isolate. J Vet Med Sci 1998, 1:107-109.

13. Tajima T, Hironao T, Kajikawa T, Suzuki Y, Kawamura H: Detection of the antibodies against porcine cytomegalovirus from whole blood collected on the blood sampling paper. J Vet Med Sci 1994, 1:189-190.

14. Widen BF, Lowings JP, Belak S, Banks M: Development of a PCR system for porcine cytomegalovirus detection and determination of the putative partial sequence of its DNA polymerase gene. Epidemiol Infect 1999, 1:177-180.

15. Hamel AL, Lin L, Sachvie C, Grudeski E, Nayar GP: PCR assay for detecting porcine cytomegalovirus. J Clin Microbiol 1999, 11:3767-3768.

16. Imirzalioglu C, Dahmen H, Hain T, Billion A, Kuenne C, Chakraborty T, Domann E: Highly Specific and Quick Detection of Mycobacterium avium subsp. paratuberculosis in Feces and Gut Tissue of Cattle and Humans by Multiple Real-Time PCR Assays. J Clin Microbiol 2011, 5:1843-1852.

17. Xu ZQ, Cheng WX, Li BW, Li J, Lan B, Duan ZJ: Development of a real-time PCR assay for detecting and quantifying human bocavirus 2. J Clin Microbiol 2011, 4:1537-1541.

18. Jacqueline FL F, Griffiths PD, Fishman JA, Emery VC, Clark DA: Quantitation of Porcine Cytomegalovirus in Pig Tissues by PCR. J Clin Microbio/ 2001, 3:1155-1156.

19. Nagata N, Kobayakawa M, Shimbo T, Hoshimoto K, Yada T, Gotoda T, Akiyama J, Oka S, Uemura N: Diagnostic value of antigenemia assay for cytomegalovirus gastrointestinal disease in immunocompromised patients. World J Gastroenterol 2011, 9:1185-1191.

20. Mao XL, Zhou S, Xu D, Gong J, Cui HC, Qin QW: Rapid and Sensitive Detection of Singapore grouper iridovirus by Loop-Mediated Isothermal Amplification. J App/ Microbiol 2008, 2:389-397.

21. Notomi T, Okayama H, Masubuchi H, Yonekawa T, Watanabe K, Amino N, Hase T: Loop-mediated isothermal amplification of DNA. Nucleic Acids Res 2000, 28:63.

22. Zhang X, Liao M, Jiao P, Luo K, Zhang H, Ren T, Zhang G, Xu C, Xin C, Cao $W$ : Development of a loop-mediated isothermal amplification assay for rapid detection of subgroup J avian leukosis virus. J Clin Microbiol 2010, 6:2116-2121.

23. Hatano B, Maki T, Obara T, Fukumoto H, Hagisawa K, Matsushita Y, Okutani A, Bazartseren B, Inoue S, Sata T, Katano H: LAMP using a disposable pocket warmer for anthrax detection, a highly mobile and reliable method for anti-bioterrorism. Jpn J Infect Dis 2010, 1:36-40.

24. Liang SY, Chan YH, Hsia KT, Lee JL, Kuo MC, Hwa KY, Chan CW, Chiang TY, Chen JS, WU FT, Ji DD: Development of loop-mediated isothermal amplification assay for detection of Entamoeba histolytica. J Clin Microbiol 2009, 6:1892-1895.

25. Arita $M$, Ling $H$, Yan D, Nishimura $Y$, Yoshida $H$, Wakita T, Shimizu $H$ : Development of a reverse transcription-loop-mediated isothermal amplification (RT-LAMP) system for a highly sensitive detection of enterovirus in the stool samples of acute flaccid paralysis cases. BMC Infect Dis 2009, 9:208.

26. Weifeng S, Kun L, Yun J, Qingbo J, Mei S, Zuhuang M: Development and evaluation of reverse transcription-loop-mediated isothermal amplification assay for rapid detection of enterovirus 71. BMC Infect Dis 2011, 1:197.

27. Njiru ZK, Mikosza AS, Armstrong T, Enyaru JC, Ndung'u JM, Thompson AR: Loop-mediated isothermal amplification (LAMP) method for rapid detection of Trypanosoma brucei rhodesiense. PLoS Negl Trop Dis 2008, $1: 147$

28. Yang J-L, Ma G-P, Yang R, Yang S-Q, Fu L-Z, Cheng A-C, Wang M-S, Zhang S-H, Shen K-F, Jia R-Y, Deng S-X, Xu Z-Y: Simple and rapid detection of Salmonella serovar Enteritidis under field conditions by loop-mediated isothermal amplification. J Appl Microbiol 2010, 5:1715-1723.
29. Mirmomeni MH, Kiani S, Sisakhtnezhad S: Rapid detection of Salmonella dublin by PCR amplification of the SopE gene and its cloning. Pak J Biol Sci 2008, 11:1497-1501.

30. Fryer JF, Griffiths PD, Emery VC, Clark DA: Susceptibility of porcine cytomegalovirus to antiviral drugs. J Antimicrob Chemother 2004, 6:975-980.

31. Ke GM, Cheng HL, Ke LY, Ji WT, Chulu JL, Liao MH, Chang TJ, Liu HJ: Development of a quantitative Light Cycler real-time RT-PCR for detection of avian reovirus. J Virol Meth 2006, 1:6-13.

32. Yang $J$, Yang $R$, Cheng AC, Wang MS, Fu LZ, Yang SQ, Zhang SH, Yang $L$, $\mathrm{Xu} Z \mathrm{Y}$ : A simple and rapid method for detection of Goose Parvovirus in the field by loop-mediated isothermal amplification. Virol J 2010, 7:14.

33. Guo Y, Cheng A, Wang M, Shen C, Jia R, Chen S, Zhang N: Development of TaqMan MGB fluorescent real-time PCR assay for the detection of anatid herpesvirus. Virol J 2009, 6:71.

34. Caliendo AM, Schuurman R, Yen-Lieberman B, Spector SA, Andersen J, Manjiry R, Crumpacker C, Lurain NS, Erice A: Comparison of quantitative and qualitative PCR assays for cytomegalovirus DNA in plasma. J Clin Microbiol 2001, 4:1334-1338.

35. Lau YL, Meganathan P, Sonaimuthu P, Thiruvengadam G, Nissapatorn V, Chen $Y$ : Specific, sensitive, and rapid diagnosis of active toxoplasmosis by a loop-mediated isothermal amplification method using blood samples from patients. J Clin Microbio/ 2010, 10:3698-3702.

36. Nkouawa A, Sako Y, Li T, Chen X, Wandra T, Swastika IK, Nakao M, Yanagida T, Nakaya K, Qiu D, Ito A: Evaluation of a loop-mediated isothermal amplification method using fecal specimens for differential detection of Taenia species from humans. J Clin Microbiol 2010, 9:3350-3352.

37. Chantratita N, Meumann E, Thanwisai A, Limmathurotsakul D, Wuthiekanun V, Wannapasni S, Tumapa S, Day NP, Peacock SJ: Loop-mediated isothermal amplification method targeting the TTS1 gene cluster for detection of Burkholderia pseudomallei and diagnosis of melioidosis. J Clin Microbiol 2008, 2:568-573.

38. Savan R, Igarashi A, Matsuoka S, Sakai M: Sensitive and rapid detection of edwardsiellosis in fish by a loop-mediated isothermal amplification method. Appl Environ Microbiol 2004, 70:621-624.

39. Yamazaki W, Seto K, Taguchi M, Ishibashi M, Inoue K: Sensitive and rapid detection of cholera toxin-producing Vibrio cholerae using a loopmediated isothermal amplification. BMC Microbiol 2008, 8:94.

40. Parida MM: Rapid and real-time detection technologies for emerging viruses of biomedical importance. J Biosci 2008, 4:617-628.

41. Tomlinson JA, Barker I, Boonham N: Faster. Simpler, More-Specific Methods for Improved Molecular Detection of Phytophthora ramorum in the Field. Appl Environ Microbiol 2007, 12:4040-4047.

doi:10.1186/1743-422X-9-321

Cite this article as: Yang et al:: Development and evaluation of a loopmediated isothermal amplification assay for the rapid detection of porcine cytomegalovirus under field conditions. Virology Journal 2012 9:321.

\section{Submit your next manuscript to BioMed Central and take full advantage of:}

- Convenient online submission

- Thorough peer review

- No space constraints or color figure charges

- Immediate publication on acceptance

- Inclusion in PubMed, CAS, Scopus and Google Scholar

- Research which is freely available for redistribution 